\title{
Monthly Urinary LH and FSH Secretory Patterns in Normal Children and Patients with Sexual Disorders
}

\author{
HATAE MAESAKA, SEIZO SUWA, KATSUHIKO TACHIBANA, AND NOBUYUKI KIKUCHI \\ Department of Pediatrics, Kanagawa Children's Medical Center, Mutsukawa 2-chome, Minami-ku, Yokohama \\ 232, Japan
}

\begin{abstract}
Urinary gonadotropin concentrations were determined by polyclonal double antibody RIA after ammonium sulfate extraction. Good correlation was observed between urinary gonadotropin/creatinine ratios in first morning voided and full 24 -h urine collections. Using consecutive 30-d first morning voided urine specimens from normal children and from patients with sexual disorders, we have studied the monthly patterns of nighttime gonadotropin secretion. In normal prepubertal girls, the levels of urinary LH were low with few variations and those of urinary FSH were higher with episodic fluctuations. In early pubertal girls, the levels of urinary LH increased with striking, rhythmic fluctuations. The same changes were seen in urinary FSH. A single big surge of urinary gonadotropins was observed in postmenarcheal girls. In normal boys, the secretory patterns of urinary gonadotropins were similar to those of normal girls, but varied less. In patients with idiopathic precocious puberty, the patterns of urinary gonadotropins were similar to those of normal subjects matched for sexual stage. The measurement of 30-d first morning voided urinary gonadotropins can provide a simple and physiologic test of gonadotropin function in children. (Pediatr Res 28: 405-410, 1990)
\end{abstract}

\section{Abbreviations}

FMV, first morning voided

The ultimate accomplishment of female gonadal function is to produce a regular ovulatory cycle. It is not fully understood how pituitary gonadotropin secretion changes from a pattern with no monthly cycle in female children to a cyclic pattern in adult women. It is proposed that the periodicity, amplitude, and frequency of gonadotropin releasing-hormone secretion increases progressively during childhood (1) and puberty begins at the stage when sufficient sexual steroids are secreted to manifest secondary sexual appearances (2). There have been few studies of monthly changes of serial serum or urinary gonadotropins in female prepubertal and pubertal children $(3,4)$.

Several studies (5-7) have shown that the diurnal patterns of LH secretion change according to the stage of sexual development and menstrual cycle. It is reported that in normal adult

Received October 25, 1989; accepted May 21, 1990.

Reprint requests: Hatae Maesaka, M.D., Department of Pediatrics, Kanagawa Children's Medical Center, Mutsukawa 2-chome, 138-4, Minami-ku, Yokohama 232, Japan.

Supported by a research grant for "Specific Disease" of the Japanese Ministry of Health and Welfare and by a comprehensive research grant regarding prevention of mental and physical disorders awarded by the Japanese Ministry of Health and Welfare. menstrual cycles, the patterns of gonadotropin excretion in FMV urine specimens corresponded to patterns in serial serum and 24-h urine specimens (8). Using this method for quantitation of urinary gonadotropins, we have demonstrated good correlation between FMV and 24-h determination of urinary gonadotropins, corrected for creatinine excretion. Using an ammonium sulfate extraction method, which was simple and required only a small amount of urine (9), we studied the patterns of urinary gonadotropins in serial FMV urine specimens obtained over a 1-mo period from normal prepubertal and pubertal children and from patients with sexual disorders.

\section{SUBJECTS}

Urine specimens were collected from 22 healthy children aged 3-16 y and two healthy adults aged 27-35 y. They were all hospital staff members and their families. FMV urine specimens were collected from these volunteers for 30 consecutive days. Of these children, three girls and one boy volunteered to collect these specimens twice at $\sim 6-$ to 12 -mo intervals. Pubertal development was assessed according to the criteria of Tanner (10). Six patients with idiopathic precocious puberty were included. According to clinical criteria, the diagnosis was established when breast buds appeared before the age of $7 \mathrm{y}$, breast buds and pubic hair before the age of $8 y$, and menarche before the age of $9 y$ in girls, and when external genitalia progressed to Tanner stage 2 before the age of $9 \mathrm{y}$ and the same changes in external genitalia associated with pubic hair occurred before the age of $10 \mathrm{y}$ in boys. In both sexes, bone age was accelerated by a minimum of at least 1.5 y compared with chronologic age. Eight patients with hypogonadotropic hypogonadism were also included. FMV urine specimens were collected from these patients for 30 consecutive days.

\section{MATERIALS AND METHODS}

Routine measurements of LH and FSH in urine after ammonium sulfate extraction were made by a polyclonal double antibody RIA kit obtained from Eiken Co., Tokyo, Japan. Extraction and RIA procedure were the same as in our previous study (9). Creatinine concentration in urine was measured by the Jaffe reaction using an autoanalyzer. Immunoreactive LH and FSH in urine were expressed as IU/g creatinine. All specimens from a single subject were assayed in the same RIA. The frequency of gonadotropin secretion was analyzed using the method of Santen and Bardin (6). A significant spontaneous LH and FSH secretory increment was defined as a rise from nadir to peak that was at least four times the corresponding intraassay coefficient of variation (11). Values are expressed as mean and SD.

RESULTS

Tables 1 and 2 summarize the urinary gonadotropin data from normal children and patients with sexual disorders. Figures 1-4 
illustrate $\mathrm{LH}$ and $\mathrm{FSH}$ patterns in normal children. Figures 5 and 6 illustrate urinary gonadotropin patterns in the patients with sexual disorders.

Normal girls (Figures $1-3$ ). The preadolescent (G1, G1') and early adolescent (G2) subjects showed low concentrations of urinary LH with little or no day-to-day variations. Urinary FSH levels in the young prepubertal girls (G1) showed random episodic fluctuations and were higher than those in the older prepubertal girls $\left(\mathrm{G}^{\prime}{ }^{\prime}\right)$ and an early adolescent girl (G2). The levels of both urinary LH and urinary FSH were low in the preadolescent subjects aged 6-11 y $\left(\mathrm{Gl}^{\prime}\right)$. In late prepubertal and early pubertal girls (subjects 18 and 19), urinary FSH excretion increased again significantly with remarkable day-to-day variations; urinary LH excretion also increased slightly with lesser variations. With progressive sexual maturation, urinary excretion of $\mathrm{LH}$ increased. In the midpubertal girls, as shown by female subject 18, urinary FSH excretion increased markedly every other day, accompanied by the same rhythmic changes in urinary LH. The high concentrations of urinary $\mathrm{LH}$ and FSH were observed with small and random fluctuations in the pubertal girls as shown by female subject 20. A single large surge of urinary LH and FSH was observed $6 \mathrm{~d}$ before menarche in the midpubertal girl (subject 21). Preceding the surge, urinary LH fluctuated episodically at an apparently higher level than that seen in the other girls. The postmenarcheal girl showed a pattern similar to that seen in two normal adult women with normal menstrual cycles (data not shown). Thirty-d FMV urine specimens were collected twice at 6-mo intervals from three normal girls as shown in Table 1 . In subject 14, the mean excretion of urinary FSH decreased, while that of $\mathrm{LH}$ did not change from 5 y 7 mo to 6 y 1 mo of age. In subject 17 , the mean excretions of both gonadotropins did not change at 9 y 7 mo of age and 6 mo

Table 1. Monthly urinary gonadotropin excretion in normal girls and boys*

\begin{tabular}{|c|c|c|c|c|c|c|c|}
\hline & & \multirow[b]{2}{*}{$\begin{array}{l}\text { Tanner } \\
\text { stage }\end{array}$} & \multirow[b]{2}{*}{$\begin{array}{l}\mathrm{CA} \\
(\mathrm{y}) \\
\end{array}$} & \multicolumn{2}{|c|}{ Urinary $\mathrm{LH}$} & \multicolumn{2}{|c|}{ Urinary FSH } \\
\hline & & & & $\begin{array}{l}\text { Mean LH } \\
\text { excretion } \\
\text { (IU/g Cr) }\end{array}$ & $\begin{array}{c}\text { Secretory } \\
\text { episodes } \\
\text { (per } \\
\text { month) }\end{array}$ & $\begin{array}{c}\text { Mean FSH } \\
\text { excretion } \\
\text { (IU/g Cr) } \\
\end{array}$ & $\begin{array}{c}\text { Secretory } \\
\text { episodes } \\
\text { (per } \\
\text { month) }\end{array}$ \\
\hline \multicolumn{8}{|l|}{ Normal boys } \\
\hline \multirow[t]{5}{*}{ G1 } & 1 & G1P1 & 6.3 & $1.4 \pm 0.2$ & 2 & $4.2 \pm 0.7$ & 2 \\
\hline & 2 & G1P1 & 8.5 & $1.3 \pm 0.4$ & 1 & $5.5 \pm 1.7$ & 3 \\
\hline & 3 & G1P1 & 9.5 & $1.0 \pm 0.4$ & 4 & $6.2 \pm 1.7$ & 5 \\
\hline & 4 & G1P1 & 13.5 & $7.5 \pm 1.2$ & 3 & $14.5 \pm 1.7$ & 3 \\
\hline & $n=4$ & mean & 9.5 & 2.8 & 2.5 & 7.6 & 3.3 \\
\hline \multirow[t]{3}{*}{ G2 } & 5 & $\mathrm{G} 2 \mathrm{P} 1$ & 10.5 & $16.5 \pm 3.2$ & 6 & $10.0 \pm 1.1$ & 0 \\
\hline & $6^{a}$ & G2P1 & 11.0 & $9.2 \pm 2.1$ & 4 & $9.8 \pm 2.8$ & 6 \\
\hline & $n=2$ & mean & 10.8 & 12.9 & 5.0 & 9.9 & 3.0 \\
\hline \multirow[t]{5}{*}{ G3 } & $6^{a}$ & G3P2 & 12.0 & $12.0 \pm 3.1$ & 5 & $8.9 \pm 1.9$ & 4 \\
\hline & 7 & G3P2 & 12.3 & $14.9 \pm 3.1$ & 5 & $9.0 \pm 1.4$ & 0 \\
\hline & 8 & G3P2 & 12.5 & $20.3 \pm 6.3$ & 4 & $10.5 \pm 3.2$ & 3 \\
\hline & 9 & G3P3 & 14.5 & $11.8 \pm 2.7$ & 1 & $6.2 \pm 1.4$ & 1 \\
\hline & $n=4$ & mean & 12.8 & 14.8 & 3.8 & 8.7 & 2.0 \\
\hline G4 & 10 & G4P3 & 16.0 & $8.9 \pm 1.0$ & 0 & $2.9 \pm 0.5$ & 0 \\
\hline \multicolumn{8}{|l|}{ Normal girls } \\
\hline \multirow[t]{5}{*}{ Gl (<6 y) } & 11 & $\mathrm{~B} 1 \mathrm{P} 1$ & 3.8 & $2.2 \pm 1.3$ & 9 & $29.0 \pm 9.6$ & 7 \\
\hline & 12 & $\mathrm{~B} 1 \mathrm{P} 1$ & 4.5 & $2.3 \pm 1.0$ & 8 & $32.9 \pm 14.2$ & 5 \\
\hline & 13 & $\mathrm{~B} I \mathrm{Pl}$ & 5.8 & $2.3 \pm 0.9$ & 4 & $13.8 \pm 7.1$ & 5 \\
\hline & $14^{b}$ & $\mathrm{~B} 1 \mathrm{P} 1$ & 5.5 & $1.2 \pm 0.9$ & 3 & $27.1 \pm 8.3$ & 4 \\
\hline & $n=4$ & mean & 4.9 & 2.0 & 6.0 & 25.7 & 5.3 \\
\hline \multirow[t]{7}{*}{$G l^{\prime}(\geq 6 y)$} & $14^{h}$ & $\mathrm{~B} 1 \mathrm{P} 1$ & 6.1 & $1.0 \pm 0.4$ & 0 & $11.4 \pm 5.2$ & 2 \\
\hline & 15 & $\mathrm{~B} 1 \mathrm{Pl}$ & 7.5 & $0.8 \pm 0.3$ & 0 & $5.6 \pm 1.5$ & 6 \\
\hline & 16 & $\mathrm{~B} 1 \mathrm{P} 1$ & 8.0 & $0.3 \pm 0.2$ & 0 & $5.4 \pm 2.0$ & 4 \\
\hline & $17^{\circ}$ & $\mathrm{B} 1 \mathrm{Pl}$ & 9.6 & $1.6 \pm 1.4$ & 3 & $9.3 \pm 5.4$ & 3 \\
\hline & $17^{c}$ & $\mathrm{~B} 1 \mathrm{P} 1$ & 10.1 & $1.3 \pm 0.5$ & 1 & $9.2 \pm 3.1$ & 7 \\
\hline & $18^{d}$ & $\mathrm{~B} 1 \mathrm{P} 1$ & 11.6 & $1.8 \pm 0.6$ & 3 & $18.7 \pm 8.6$ & 5 \\
\hline & $n=6$ & mean & 8.8 & 1.1 & 1.2 & 9.9 & 4.5 \\
\hline G2 & 19 & $\mathrm{~B} 2 \mathrm{P} 1$ & 11.1 & $2.1 \pm 1.1$ & 3 & $12.6 \pm 3.7$ & 8 \\
\hline \multirow[t]{4}{*}{ G3 } & $18^{d}$ & B3P1 & 12.1 & $9.8 \pm 5.4$ & 11 & $13.2 \pm 7.0$ & 11 \\
\hline & 20 & B3P1 & 13.3 & $18.3 \pm 3.1$ & 2 & $17.6 \pm 5.7$ & 7 \\
\hline & 21 & B3P1M & 12.3 & $58.1 \pm 34.5$ & 7 & $23.2 \pm 12.2$ & 4 \\
\hline & $n=3$ & mean & 12.6 & 28.7 & 6.7 & 18.0 & 7.3 \\
\hline G4 & 22 & $\mathrm{~B} 4 \mathrm{P} 3 \mathrm{M}$ & 14.6 & $31.0 \pm 30.9$ & 1 & $11.6 \pm 9.3$ & 1 \\
\hline
\end{tabular}

* Values are the mean \pm SD. CA, chronologic age; G, genitalia; $P$, pubic hair; $B$, breast; $M$, menstruation. The same children have the same number and are followed by a superscript. The pubertal stage $G 1$ in girls was divided into two subgroups: Gl when CA has not reached 6 y, and $\mathrm{Gl}^{\prime}$ when $\mathrm{CA}$ was 6 y or greater. 
Table 2. Monthly urinary gonadotropin excretion in patients with idiopathic precocious puberty and hypogonadotropic hypogonadism*

\begin{tabular}{|c|c|c|c|c|c|c|c|c|c|}
\hline \multirow[b]{2}{*}{ Subject } & \multirow[b]{2}{*}{$\begin{array}{c}\mathrm{CA} / \mathrm{BA} \\
(\mathrm{y})\end{array}$} & \multicolumn{3}{|c|}{ Tanner stage } & \multicolumn{2}{|c|}{ Urinary LH } & \multicolumn{2}{|c|}{ Urinary FSH } & \multirow[b]{2}{*}{ Treatment at study } \\
\hline & & Testis & Penis & $\begin{array}{l}\text { Pubic } \\
\text { hair }\end{array}$ & $\begin{array}{l}\text { Mean LH } \\
\text { excretion } \\
(\mathrm{IU} / \mathrm{g} \mathrm{Cr})\end{array}$ & $\begin{array}{c}\text { Secretory } \\
\text { episodes } \\
\text { (per month) }\end{array}$ & $\begin{array}{c}\text { Mean FSH } \\
\text { excretion } \\
(\mathrm{IU} / \mathrm{g} \mathrm{Cr})\end{array}$ & $\begin{array}{c}\text { Secretory } \\
\text { episodes } \\
\text { (per month) }\end{array}$ & \\
\hline \multicolumn{10}{|l|}{ Male patients } \\
\hline $\begin{array}{l}\text { (23) Idiopathic pituitary } \\
\text { dwarf }\end{array}$ & $14.8 / 10.6$ & $2 \mathrm{~mL} ; 2 \mathrm{~mL}$ & $1^{\circ}$ & $1^{\circ}$ & $2.3 \pm 0.8$ & 0 & $1.8 \pm 1.2$ & 0 & $\mathrm{hGH}$ \\
\hline $\begin{array}{l}\text { (24) Organic panhypopi- } \\
\text { tuitarism }\end{array}$ & $17.4 / 13.5$ & $2 \mathrm{~mL} ; 2 \mathrm{~mL}$ & $1^{\circ}$ & $1^{\circ}$ & $0.6 \pm 0.5$ & 0 & $0.9 \pm 0.7$ & 0 & $\begin{array}{l}\text { hGH, thyroxine, } \\
\text { hydrocortisone }\end{array}$ \\
\hline $\begin{array}{l}\text { (25) Idiopathic pituitary } \\
\text { dwarf }\end{array}$ & $16.7 / 13.5$ & $1 \mathrm{~mL} ; 1 \mathrm{~mL}$ & $1^{\circ}$ & $1^{\circ}$ & $0.5 \pm 0.2$ & 0 & $0.7 \pm 0.2$ & 0 & hGH, thyroxine \\
\hline $\begin{array}{l}\text { (26) Idiopathic hypogona- } \\
\text { dotropic hypogonadism }\end{array}$ & $16.9 / 14.0$ & $1 \mathrm{~mL} ; 1 \mathrm{~mL}$ & $1^{\circ}$ & $1^{\circ}$ & $2.0 \pm 0.3$ & 0 & $2.2 \pm 0.6$ & 0 & \\
\hline $\begin{array}{l}\text { (27) Idiopathic hypogona- } \\
\text { dotropic hypogonadism }\end{array}$ & $15.1 / 13.5$ & $2 \mathrm{~mL} ; 1 \mathrm{~mL}$ & $1^{\circ}$ & $1^{\circ}$ & $0.2 \pm 0.2$ & 0 & $0.9 \pm 0.2$ & 0 & \\
\hline \multirow{2}{*}{$\begin{array}{l}\text { (28) Idiopathic precocious } \\
\text { puberty }\end{array}$} & $9.4 / 13.0$ & $10 \mathrm{~mL} ; 10 \mathrm{~mL}$ & $3^{\circ}$ & $2^{\circ}$ & $18.7 \pm 4.7$ & 5 & $11.0 \pm 2.5$ & 3 & DDAVP, thyroxine \\
\hline & \multicolumn{4}{|c|}{ Pubic } & & & & & \\
\hline \multicolumn{10}{|l|}{ Female patients } \\
\hline $\begin{array}{l}\text { (29) Idiopathic precocious } \\
\text { puberty }\end{array}$ & $6.2 / 7.7$ & $3^{\circ}$ & $1^{\circ}$ & & $10.6 \pm 5.5$ & 12 & $19.5 \pm 10.2$ & 13 & \\
\hline $\begin{array}{l}\text { (30) Idiopathic precocious } \\
\text { puberty }\end{array}$ & $8.8 / 10.5$ & $3^{\circ}$ & $2^{\circ}$ & & $20.2 \pm 8.0$ & 8 & $34.8 \pm 11.3$ & 7 & \\
\hline $\begin{array}{l}\text { (31) Idiopathic precocious } \\
\text { puberty }\end{array}$ & $8.8 / 10.5$ & $3^{\circ}$ & $3^{\circ}$ & & $21.8 \pm 6.2$ & 4 & $31.0 \pm 7.1$ & 5 & \\
\hline $\begin{array}{l}\text { (32) Idiopathic precocious } \\
\text { puberty }\end{array}$ & $9.9 / 11.8$ & $4^{\circ}$ & $2^{\circ}$ & & $16.6 \pm 3.2$ & 6 & $17.6 \pm 3.3$ & 6 & \\
\hline $\begin{array}{l}\text { (33) Idiopathic precocious } \\
\text { puberty }\end{array}$ & $6.8 / 8.8$ & $4^{\circ}$ & $2^{\circ}$ & & $24.7 \pm 13.5$ & 5 & $14.7 \pm 3.3$ & 6 & \\
\hline $\begin{array}{l}\text { (34) Organic panhypopi- } \\
\text { tuitarism }\end{array}$ & $17.8 / 13.0$ & $1^{\circ}$ & $1^{\circ}$ & & $0.9 \pm 0.9$ & 0 & $0.9 \pm 0.7$ & 0 & $\begin{array}{l}\text { hGH, DDAVP, } \\
\text { thyroxine }\end{array}$ \\
\hline $\begin{array}{l}\text { (35) Organic panhypopi- } \\
\text { tuitarism }\end{array}$ & $15.2 / 11.5$ & $2^{\circ}$ & $1^{\circ}$ & & $0.9 \pm 0.3$ & 0 & $2.2 \pm 1.9$ & 0 & $\begin{array}{l}\text { hGH, DDAVP, } \\
\text { thyroxine }\end{array}$ \\
\hline $\begin{array}{l}\text { (36) Idiopathic pituitary } \\
\text { dwarf }\end{array}$ & $14.4 / 13.5$ & $2^{\circ}$ & $1^{\circ}$ & & $0.2 \pm 0.2$ & 0 & $0.6 \pm 0.2$ & 0 & $\mathrm{hGH}$, thyroxine \\
\hline
\end{tabular}

${ }^{*} \mathrm{CA}$, chronologic age; BA, bone age; DDAVP, desmospressin (desamino-8-D-arginine vasopressin).
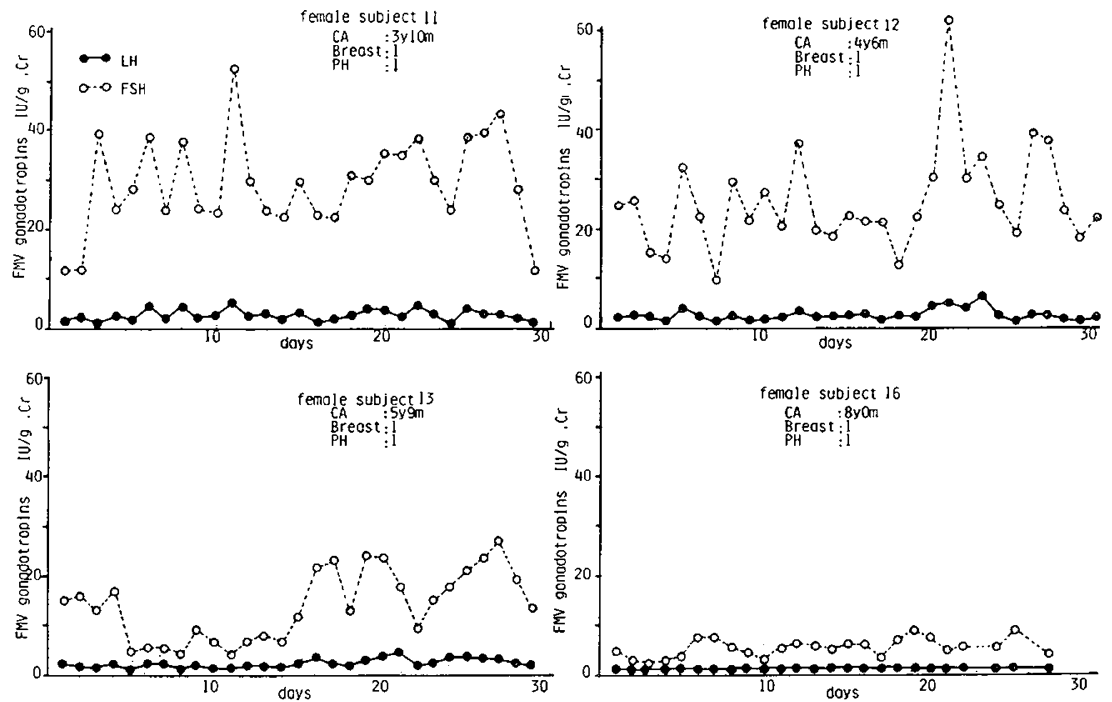

Fig. 1. Urinary LH and FSH patterns in four prepubertal girls. $C A$, chronologic age; $P H$, pubic hair.

after. However, subject 18 showed different patterns of urinary $\mathrm{LH}$ and FSH at 11 y 7 mo and 12 y 1 mo of age. In the first urine collection, she had no breast budding and the concentrations of urinary FSH were elevated with random fluctuations throughout the $30-\mathrm{d}$ period like those of subject 17 . She devel- oped breast budding after the first urine collection period. In the second collection period, rhythmic fluctuations in urinary $\mathrm{LH}$ and FSH appeared throughout the month as described above.

Normal boys (Figure 4). Before the onset of puberty (G1), the concentrations of urinary LH and FSH were low with small and 

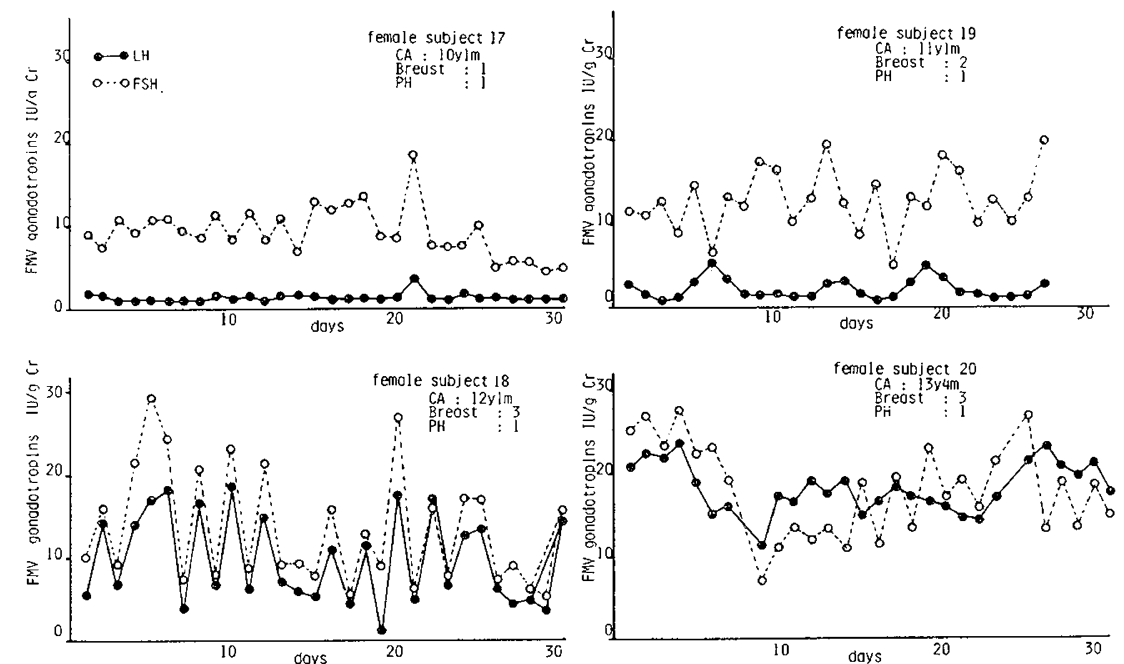

Fig. 2. Urinary $\mathrm{LH}$ and FSH patterns in four pubertal girls. $C A$, chronologic age; $P H$, pubic hair.

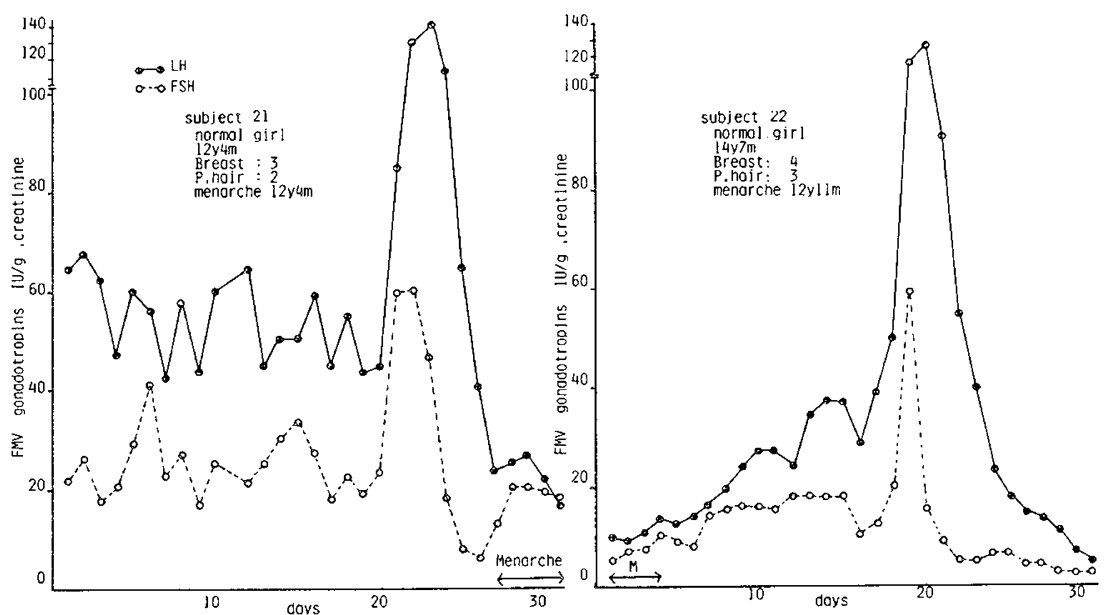

Fig. 3. Monthly urinary LH and FSH excretion patterns in normal postmenarcheal girls. $M$, menstruation.
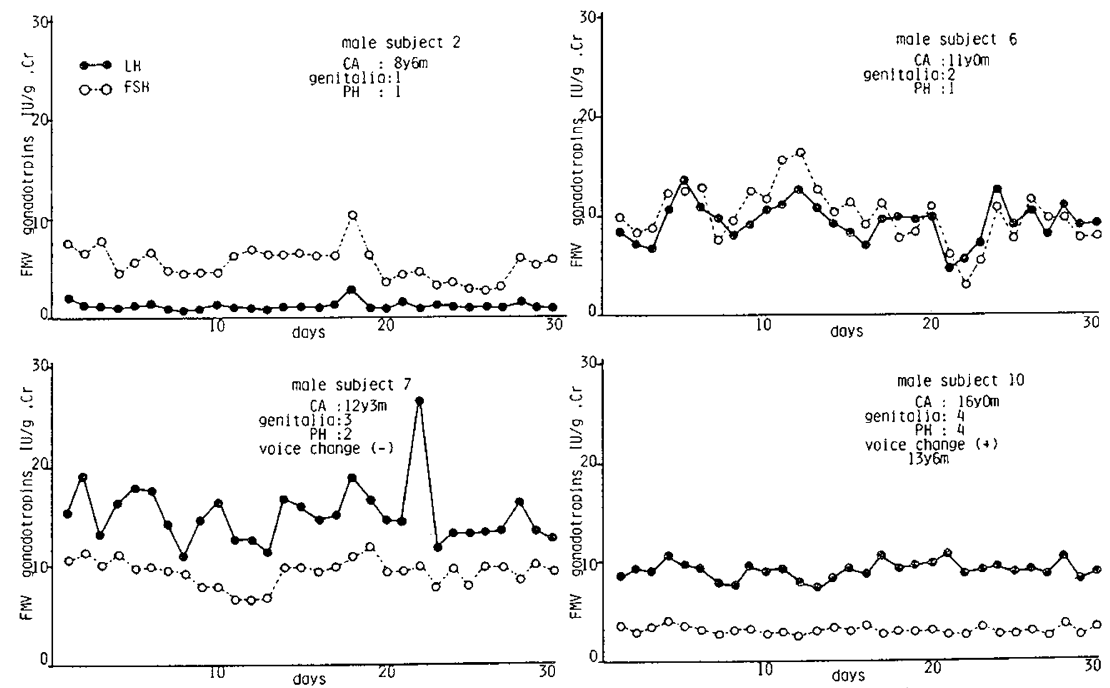

Fig. 4. Urinary LH and FSH patterns in one prepubertal and three pubertal boys. $C A$, chronologic age; $P H$, pubic hair.

random fluctuations. In early and midpubertal boys, urinary $\mathrm{LH}$ increased rapidly with random episodic fluctuations. Little variation was observed in urinary FSH. Thirty-d FMV urine specimens were collected twice at 12 -mo intervals from subject 6 as shown in Table 1. Subject 6 showed different patterns of urinary LH and FSH at 11 y 0 mo and 12 y 0 mo of age. In the first urine collection period, his external genitalia were Tanner stage 2. In the second collection period, he developed pubic hair and showed patterns similar to those in subject 7 . In a late pubertal boy (subject 10), the levels of urinary LH and FSH decreased with little variation as shown in Table 1 and Figure 4.

Precocious puberty (Figures 5 and 6). The secretory patterns 

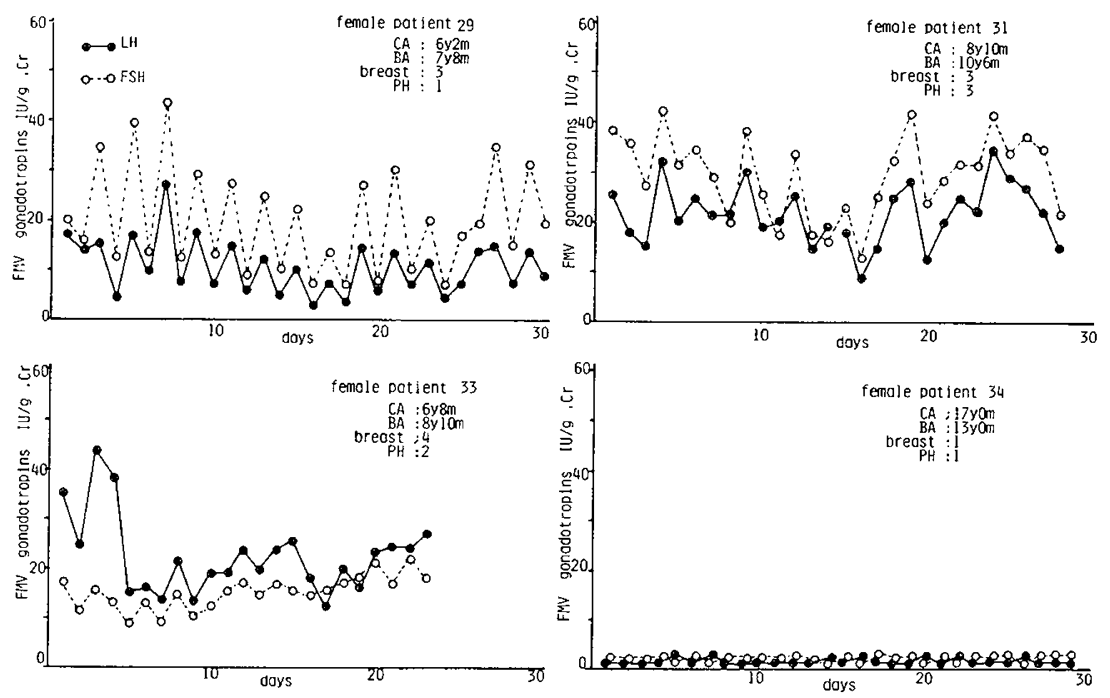

Fig. 5. Urinary LH and FSH patterns in female patients with idiopathic precocious puberty and hypogonadotropic hypogonadism. $C A$, chronologic age; $B A$, bone age; $P H$, pubic hair.
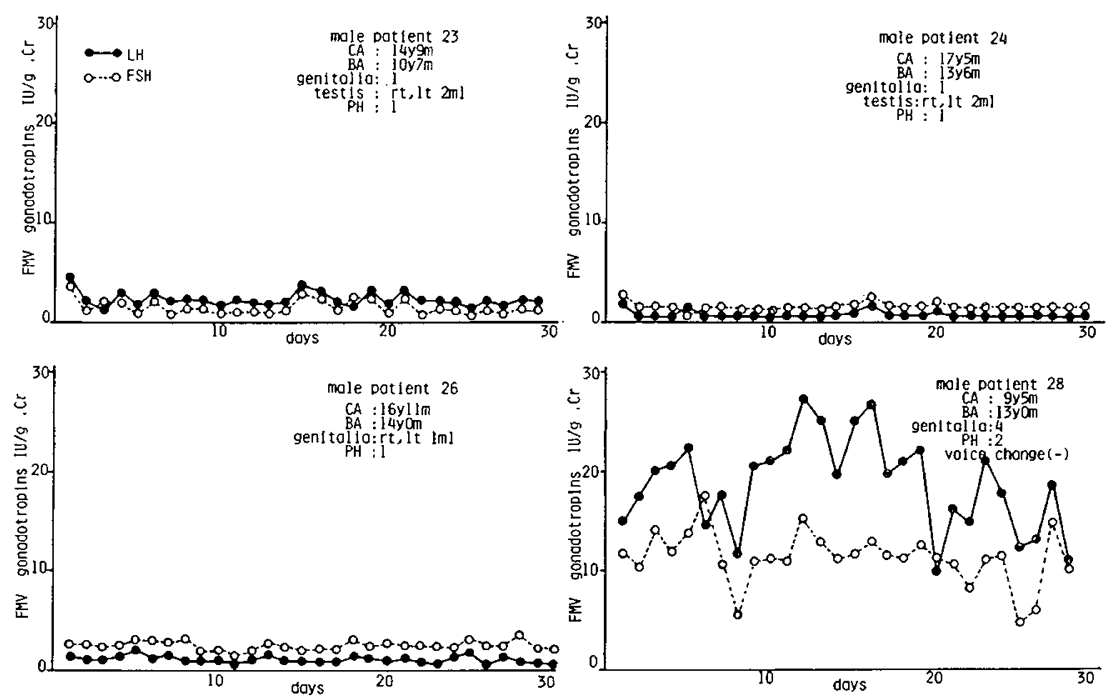

Fig. 6. Urinary LH and FSH patterns in male patients with hypogonadotropic hypogonadism and idiopathic precocious puberty. $C A$, chronologic age; $B A$, bone age; $P H$, pubic hair.

of urinary $\mathrm{LH}$ and FSH were different, depending on the stage of sexual maturation in three female patients (subjects 29, 31, and 33). The patterns of urinary gonadotropins in the two patients (subjects 29 and 31) were similar to those in normal pubertal girls aged $>12$ y (subjects 18 and 20). The secretory patterns of urinary LH and FSH in the male patient (subject 6) were also similar to those for his bone age-matched normal boy (subject 7). Moreover, the mean urinary excretion of LH in these patients tended to be higher than those in sexual stage-matched normal children.

Hypogonadotropic hypogonadism (Figures 5 and 6). The urinary gonadotropin excretions in these patients were low with no definite fluctuations.

\section{DISCUSSION}

There are many reports about the diurnal changes in the levels of serum gonadotropins in children and adults $(5-7,12,13)$. However, there are few reports $(3,4)$ about the monthly changes of serum and urinary gonadotropins in children and adults except those of menstruating adult women. Hansen et al. (3) showed that there were monthly cycles of urinary LH and FSH excretion in premenarcheal and postmenarcheal girls. There are no reports of the monthly changes of urinary gonadotropins in boys. Winter et al. (4) reported no hormone rhythms in prepubertal girls, random episodic fluctuations in FSH in early pubertal girls, and midcycle FSH/LH peak in postmenarcheal girls while studying the levels of serum gonadotropins obtained at 2- to 3-d intervals for $35 \mathrm{~d}$ from healthy prepubertal and pubertal girls. In our studies, monthly urinary FSH excretions in young prepubertal children were higher than those in older prepubertal and early pubertal children. Whenever the levels of urinary FSH were high, FSH seemed to fluctuate more markedly than LH. These results are consistent with urinary gonadotropin results reported by Hansen et al. (3). Kulin and Reiter (14) reported that the major change in urinary gonadotropins during puberty was in $\mathrm{LH}$ excretion, although the first detectable change might be the increment of urinary FSH excretion. Episodic secretion of FSH might not be seen in serial blood samples obtained over $24 \mathrm{~h}$ due to its relatively long $t_{1 / 2}$ in the circulation. After the onset of puberty, the excretion of urinary $\mathrm{LH}$ increased significantly and there were striking, rhythmic fluctuations in both gonadotropins. The same patterns of monthly urinary LH and FSH excretion were observed in three other female patients with idiopathic precocious puberty during treatment with medroxyprogesterone acetate and cyproterone acetate (data not shown). The possible physiologic significance of these patterns remains to be elucidated. In the premenarcheal patient with precocious puberty 
(subject 33), a surge-like LH excretion was observed without an accompanying elevation of urinary FSH, similar to the findings in premenarcheal girls reported by Hansen et al. (3). It remains to be elucidated whether those patients are transient patterns before the midcycle $\mathrm{FSH} / \mathrm{LH}$ surge in menstrual-cycled adults.

It remains possible that the fluctuations observed in premenarcheal girls represent an artifact, although every attempt was made to exclude this possibility. All urine samples from the same child were measured in the same RIA to minimize interassay artifacts. Gonadotropin recoveries were uniformly high and variations in recovery were much less than the observed fluctuations in urinary gonadotropin levels. It is possible, however, that variability in the time between the last micturition before sleep and the FMV urine, variability in the quantity of creatinine excreted overnight, or unaccounted-for nocturnal voidings contributed an impression of fluctuation in hormonal excretion. In our opinion, however, the rhythmic nature of the observed fluctuations speaks against these presumably random artifactual events.

Similar but less marked changes were observed in prepubertal boys. With advancing sexual stage, amounts of urinary LH excretion increased with the predominance of fluctuations in male pubertal children. In late pubertal boys, as shown by male subject 10 , the amounts and variations of urinary $\mathrm{LH}$ and FSH decreased compared with those of early and midpubertal boys. In the patients with hypogonadotropic hypogonadism, urinary LH and FSH excretion were constantly low with no day-to-day variations, suggesting that there had been no pulsatile secretion of gonadotropin-releasing hormone in these patients.

From our study, we conclude that the patterns of urinary gonadotropin excretion change definitely and rapidly with the progression of sexual maturation. These serial determinations of urinary LH and FSH seem to be a simple and physiologic test of gonadotropin function in normal children and in patients with sexual disorders. These serial urinary gonadotropin measurements are capable of disclosing the transition from prepubertal to adult hypothalamo-pituitary-gonadotropin function and identifying the stage of female sexual development at which cyclic pituitary-ovarian function begins. However, these RIA for $\mathrm{LH}$ and FSH do not measure bioactive gonadotropin concentrations and may not accurately reflect the activity of the reproductive unit for this reason.

Acknowledgments. The authors thank Y. Ogawa, Kanagawa Children's Medical Center, for the measurement of urinary creatinine.

\section{REFERENCES}

1. Boyar RM, Finkelstein J, Roffwarg H, Kapen S, Weitzman E, Hellman L 1972 Synchronization of augmented luteinizing hormone secretion with sleep during puberty. N Engl J Med 287:582-586

2. Stanhope R, Brook CGD, Pringle PJ, Adams J, Jacobs HS 1987 Induction of puberty by pulsatile gonadotrophin-releasing hormone. Lancet 2:552-555

3. Hansen JW, Hoffman HJ, Ross GT 1975 Monthly gonadotropin cycles in premenarcheal girls. Science 190:161-163

4. Winter JSD, Faiman C 1973 The development of cyclic pituitary-gonadal function in adolescent females. J Clin Endocrinol Metab 37:714-718

5. Penny R, Olambiwonnu NO, Frasier SD 1977 Episodic fluctuations of serum gonadotropins in pre- and post-pubertal girls and boys. J Clin Endocrinol Metab 45:307-311

6. Santen RJ, Bardin DW 1973 Episodic luteinizing hormone secretion in man $\mathrm{J}$ Clin Invest 52:2617-2628

7. Growley WF, William F, Filicori JM, Spratt DI, Santoro NF 1985 Physiology of GnRH secretion in men \& women. Recent Prog Horm Res 41:473-526

8. Hansen JW, Ross GT 1975 A new method simplifying collection of serial specimens for gonadotropin determinations. J Clin Endocrinol Metab 41:241-244

9. Maesaka H, Suwa S, Tachibana K, Kikuchi N 1990 Quantitation of urinary gonadotropins in normal children. Pediatr Res 28:401-404

10. Tanner JM 1962 Growth of Adolescence. 2nd Ed. Blackwell, Oxford

11. Veldhuis JD, Rogol AD, Johnson ML 1985 Minimizing false-positive errors in hormonal pulse detection. Am J Physiol 248:E475-E481

12. Corley KP, Valk TW, Kelch RP, Marshall JC 1981 Estimation of GnRH pulse amplitude during pubertal development. Pediatr Res 15:157-162

13. Jakacki RI, Kelch RP, Sauder SE, Lloyd JS, Hopwood NJ, Marshall JC 1982 Pulsatile secretion of Luteinizing hormone in children. $\mathrm{J}$ Clin Endocrinol Metab 55:453-458

14. Kulin H, Reiter EO 1973 Gonadotropin during childhood and adolescence: a review. Pediatrics 51:260-271 